\title{
KEY CONSIDERATIONS \\ OPERATIONAL CONSIDERATIONS FOR BUILDING COMMUNITY RESILIENCE FOR COVID-19 RESPONSE AND RECOVERY
}

As the unequal impact of the COVID-19 pandemic continues, there is a need to robustly support vulnerable communities and bolster 'community resilience.' A community resilience approach means to work in partnership with communities and strengthen their capacities to mitigate the impact of the pandemic, including its social and economic fallout. ${ }^{-3}$ However, this is not resilience which returns the status quo. This moment demands transformative change in which inequalities are tackled and socioeconomic conditions are improved. While a community resilience approach is relatively new to epidemic preparedness and response, it frames epidemic shocks more holistically and from the perspective of a whole system..$^{4-6}$

While epidemic response often focuses on mitigating vulnerabilities, there is an opportunity to use a resilience framework to build existing capacities to manage health, social, psychosocial, and economic impacts of an epidemic. This makes a resilience approach more localised, adaptable, and sustainable in the long-term, which are key tenets of an epidemic response informed by social science..$^{-9}$ This brief presents considerations for how health and humanitarian practitioners can support communities to respond to and recover from COVID-19 using a community resilience approach. This brief was developed for SSHAP by IDS (led by Megan Schmidt-Sane with Tabitha Hrynick) with Anthrologica (Eva Niederberger) and is the responsibility of SSHAP.

\section{WHAT IS COMMUNITY RESILIENCE?}

Community resilience is both a process and an outcome that emphasises local capacities which can be adapted (e.g., adaptive capacities) and used during a crisis to cope, to mitigate harm, and recover after one. ${ }^{6}$ A community is defined here as a group of individuals sharing common characteristics. ${ }^{10}$ A resilient community is one that builds on local strengths, or community's capacities, skills, and knowledge that can be used for recovery from crisis or shock." Human and social capacities might include the following. 
- Local knowledge, or experience to address specific needs and propose solutions or interventions. Past work has leveraged existing local knowledge on how to prevent and contain epidemics like Ebola for a more locally relevant epidemic response. ${ }^{12,13}$

- Technical capacity in the community (e.g., potable water distribution, vulnerable household identification, food security) which can be strengthened.

- Community networks and relationships, or the connectedness of a community is defined by linkages within a community based on social or kin relationships. They can improve community resilience by actively and meaningfully engaging networks during an emergency or shock. These networks have been used to coordinate a response, distribute supplies, and respond to emergency needs. ${ }^{14}$

- Governance and leadership are vital capacities that shape how communities handle crisis, how decisions are made, who receives support and resources, and whether a response is trusted. ${ }^{4}$

These capacities must be complemented by an enabling environment. National and regional governments, development, and humanitarian actors should provide targeted support, including resources like equipment or training.

Supporting community resilience involves building on local capacities and recognising and addressing local inequalities, power relations, and social tensions. It requires core principles of equity and fairness in access to resources so that existing vulnerabilities are not exacerbated during a time of crisis. ${ }^{15}$ A 'transformative,' or social justice-oriented community resilience approach can build equity in the longer term, distribute resources equitably, and strengthen the capacities and resilience of a community's most vulnerable. ${ }^{16}$

\section{COVID-19 AND EXISTING COMMUNITY CAPACITIES}

The COVID-19 pandemic has quickly developed into one of the largest global disruptions of our lifetimes. It has not only impacted millions who have contracted the disease, but it has put massive pressure on health, social, and economic systems.' COVID-19 added additional stress to already difficult circumstances for many communities. It has amplified how issues of governance, inequalities, social cohesion and inclusion matter. COVID-19 is not a short-term shock, but it has become a protracted crisis disproportionately affecting the world's most vulnerable. ${ }^{17}$

During the pandemic, communities have developed and managed diverse support networks to address and mitigate short- and long-term impact. ${ }^{18}$ Community responses 
contribute to improved access to basic services - often complementing or even substituting delays in government response. For example, in Argentina, a faith-based network supported local approaches to shield the elderly. In Kenya, a slum-dweller organisation collected information on COVID-19 in informal settlements, identified community level isolation areas and fed into governmental guidelines on isolation. ${ }^{9} \mathrm{In}$ India, women micro-entrepreneurs developed and distributed millions of face masks. ${ }^{19}$

These are all examples of community responses to COVID-19 that can be more systematically strengthened and supported in order to build community-level recovery and a community's ability to withstand future shocks. Building community resilience is not a substitute for government services or support which will be required to address inequalities in areas which are socioeconomically disadvantaged and lack communitybased resources. ${ }^{19}$

\section{OPERATIONALISING COMMUNITY RESILIENCE FOR RESPONSE AND RECOVERY FROM COVID-19}

We present specific suggestions for health and humanitarian practitioners who might consider a community resilience approach to support COVID-19 response and recovery. It is vital to think of communities as partners in an epidemic response and consider both their health and livelihood needs. In the longer-term, practitioners can build up community capacities that link into and address social determinants of health. Some of the main themes from research and practice in community resilience with lessons for COVID-19 response and recovery include to:

1. Integrate communities' local knowledge on how to prevent and contain infectious diseases. As evidenced in past Ebola outbreaks, using communities as local partners in an epidemic response can lead to more acceptable public health measures. $4,5,13$ Public health practitioners can work with communities to leverage their existing knowledge and integrate it into an epidemic response.

2. Support community-led actions for recovery. Public health has a critical role in creating an enabling environment and supporting a community-led process. ${ }^{20}$ This means community-led action in the mid- to long-term, underpinned by mechanisms which foster trust and enable the participation of those involved in local governance and leadership. It also means an inclusive approach to local planning and decisionmaking around shared resources - supported by partnership arrangements with community networks and flexible funding mechanisms and community grants for needs-based support. 16,20 
3. Strengthen adaptive capacities. Communities can quickly adapt to a 'new normal' during times of crisis. However, we should support the well-being of a community. Social capital, new skills and training as well as access to financial capital and livelihood options are all features of adaptive capacity.

4. Build back more equitably through a 'transformative approach,' rather than just returning to normal. With a focus on particularly vulnerable and marginalised population groups, support could range from immediate cash and food assistance to developing sustainable livelihood options and improving social protection mechanisms. ${ }^{22}$

5. Address inequalities, which will help to build social cohesion and is critical for reaching the most vulnerable. While COVID-19 triggered a variety of locally-led actions helping communities to absorb immediate shocks, more recent research found lower levels of social cohesion as the pandemic evolved. ${ }^{21}$

6. Use a systems approach, which will require building the resilience of market systems and health systems. Programming should acknowledge resilience at multiple, interconnected levels of society. By taking a systems approach, it is possible to create an enabling environment that supports resilience at the community level.

7. Acknowledge that communities are dynamic and complex. It will help to understand local realities, power dynamics and how communities perceive risks - and plan for support in response to diverse needs and realities. Community-based networks can provide valuable insights into the local context and are often trusted advisors. Customary leadership can also be supported to provide an enabling environment for building resilience. Approaches could involve rapid assessments of vulnerabilities and capacities as well as more granular social science research using participatory methods..$^{23,24}$

8. Recognise the unique needs of urban areas. Community resilience research is generally lacking in urban areas. These recommendations include pursuing resilient urban development and design and integrating multisectoral response. ${ }^{25}$

9. Fund community organisations using a flexible funding model to provide support to organisations already engaged in recovery efforts, address the immediate and longterm needs of a community, and align with community priorities. ${ }^{26,27}$ 


\section{OTHER RESOURCES}

- Mercy Corps, Strategic resilience assessment (STRESS):

https://www.mercycorps.org/research-resources/strategic-resilience-assessment

- Care International, More Equal - More Resilient:

https://insights.careinternational.org.uk/publications/more-equal-more-resilient-

why-care-international-is-making-gender-equality-and-women-s-empowerment-a-

priority-for-community-based-adaptation

- The Oxfam Framework and Guidance for Resilient Development:

https://oxfamilibrary.openrepository.com/bitstream/handle/10546/604990/ml-

resilience-framework-guide-120416-en.pdf?sequence=1\%C2\%AO

- United Nations. 'Sendai Framework for Disaster Risk Reduction 2015-2030':

https://www.undrr.org/publication/sendai-framework-disaster-risk-reduction-2015-

2030

\section{ACKNOWLEDGMENTS}

We would like to thank Kelsey Weber (International Rescue Committee), Danielle Jolicoeur (Mercy Corps), Karla Peña (Mercy Corps) and Olivia Tulloch (Anthrologica) for their input and review.

\section{CONTACT}

If you have a direct request concerning the response to COVID-19, regarding a brief, tools, additional technical expertise or remote analysis, or should you like to be considered for the network of advisers, please contact the Social Science in Humanitarian Action Platform by emailing Annie Lowden (a.lowden@ids.ac.uk) or (oliviatulloch@anthrologica.com). Key Platform liaison points include: UNICEF (nnaqvi@unicef.org); IFRC (ombretta.baggio@ifrc.org); and GOARN Research Social science Group (nina.gobat@phc.ox.ac.uk).
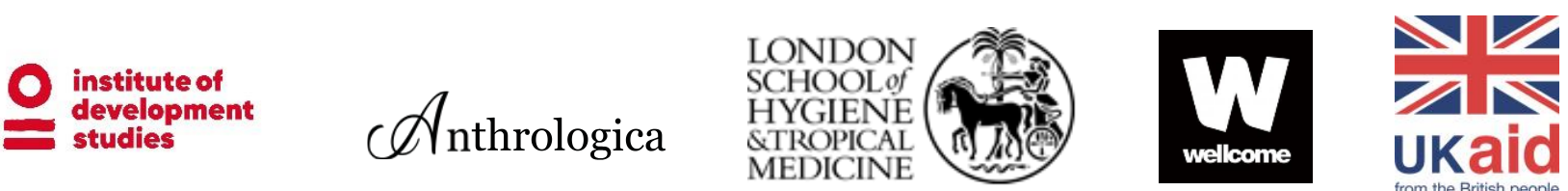

veroaide 
The Social Science in Humanitarian Action is a partnership between the Institute of Development Studies, Anthrologica and the London School of Hygiene and Tropical Medicine. Funding to support the Platform's response to COVID-19 has been provided by the Wellcome Trust and FCDO. The opinions expressed are those of the authors and do not necessarily reflect the views or policies of IDS, Anthrologica, LSHTM, Wellcome Trust or the UK government..

Suggested citation: Schmidt-Sane, M., Niederberger, E., \& Hrynick, T., 'Key Considerations: Operational Considerations for Building Community Resilience for COVID-19 Response and Recovery,' Brighton: Social Science in Humanitarian Action (SSHAP) DOI: 10.19088/SSHAP.2021.002

\section{Published January 2021}

(c) Institute of Development Studies 2021

This is an Open Access paper distributed under the terms of the Creative Commons Attribution 4.0 International licence (CC BY), which permits unrestricted use, distribution, and reproduction in any medium, provided the original authors and source are credited and any modifications or adaptations are indicated. 
1. Building Community Resilience in the Face of Covid-19. (n.d.). Retrieved 7 October 2020, from/news/2020/04/03/building-communityresilience-in-the-face-of-covid-19/

2. Strengthened community resilience and COVID-19 response through community action interventions (2020). (n.d.). Retrieved 7 October 2020, from https://www.euro.who.int/en/health-topics/environment-and-health/urban-health/who-europeanhealthy-cities-network/key-publications/strengthened-community-resilience-and-covid-19-response-through-communityaction-interventions-2020

3. Penkler, M., Müller, R., Kenney, M., \& Hanson, M. (2020). Back to normal? Building community resilience after COVID-19. The Lancet Diabetes \& Endocrinology, 8(8), 664-665. https://doi.org/10.1016/S2213-8587(20)30237-0

4. Alonge, O., Sonkarlay, S., Gwaikolo, W., Fahim, C., Cooper, J. L., \& Peters, D. H. (2019). Understanding the role of community resilience in addressing the Ebola virus disease epidemic in Liberia: A qualitative study (community resilience in Liberia). Global Health Action, 12(1), 1662682. https://doi.org/10.1080/16549716.2019.1662682

5. Sonarkley, S. (n.d.). Community Resilience in the context of the Ebola Virus Disease epidemic in Liberia. Future Health Systems. Retrieved 29 November 2020, from http://www.futurehealthsystems.org/blog/2018/6/12/community-resilience-in-the-contextof-the-ebola-virus-disease-epidemic-in-liberia

6. Schmidt-Sane, M., Hrynick, T., \& Niederberger, E. (n.d.). Community resilience: Key concepts and applications to epidemic shocks Social Science in Humanitarian Action (SSHAP).

7. Uganda-DRC Cross-Border Dynamics. (n.d.). Social Science in Humanitarian Action Platform. Retrieved 17 December 2020 , from https://www.socialscienceinaction.org/resources/uganda-drc-cross-border-dynamics/

8. Gender Inclusiveness in COVID-79 Humanitarian Response Operations, Evidence from Social Sciences Outbreak Research. (n.d.). Social Science in Humanitarian Action Platform. Retrieved 17 December 2020, from http://ssia.local/resources/genderinclusiveness-covid-19-humanitarian-response-operations-evidence-social-sciences-outbreak-research/

9. One Size Does Not Fit All: COVID-79 Responses Across African Settings. (n.d.). Social Science in Humanitarian Action Platform. Retrieved 17 December 2020, from http://www.socialscienceinaction.org/resources/one-size-does-not-fit-all-covid-19responses-across-african-settings/

10. Wilkinson A., Parker M., Martineau F., \& Leach M. (2017). Engaging 'communities': Anthropological insights from the West African Ebola epidemic. Philosophical Transactions of the Royal Society B: Biological Sciences, 372(1721), 20160305. https://doi.org/10.1098/rstb.2016.0305

11. Norris, F. H., Stevens, S. P., Pfefferbaum, B., Wyche, K. F., \& Pfefferbaum, R. L. (2008). Community resilience as a metaphor, theory, set of capacities, and strategy for disaster readiness. American Journal of Community Psychology, 47(1-2), 127-150. https://doi.org/10.1007/s10464-007-9156-6

12. Hewlett, B. S., \& Amola, R. P. (2003). Cultural Contexts of Ebola in Northern Uganda. Emerging Infectious Diseases, 9(10), 1242-1248. https://doi.org/10.3201/eid0910.020493

13. Hewlett, B. S., \& Hewlett, B. L. (2007). Ebola, Culture and Politics: The Anthropology of an Emerging Disease. Cengage Learning.

14. Community Resilience in the Time of COVID-19: Lessons from the 2017 Mexican Earthquakes - Inter-American Foundation. (n.d.). Inter-American Foundation. Retrieved 7 October 2020, from https://www.iaf.gov/content/story/community-resilience-in-thetime-of-covid-19/

15. Allmark, P., Bhanbhro, S., \& Chrisp, T. (2014). An argument against the focus on Community Resilience in Public Health. BMC Public Health, 14, 62. https://doi.org/10.1186/1471-2458-14-62

16. Rippon, S., Bagnall, A.-M., Gamsu, M., South, J., Trigwell, J., Southby, K., Warwick-Booth, L., Coan, S., \& Woodward, J. (2020). Towards transformative resilience: Community, neighbourhood and system responses during the COVID-19 pandemic. Cities \& Health, O(0), 1-4. https://doi.org/10.1080/23748834.2020.1788321

17. IIED. (2020). Emerging lessons from community-led COVID-19 responses in urban areas. https://www.iied.org/emerging-lessonscommunity-led-covid-19-responses-urban-areas

18. Coronavirus volunteering: How you can help through a mutual aid group-Vox. (n.d.). Retrieved 29 November 2020 , from https://www.vox.com/future-perfect/2020/3/24/21188779/mutual-aid-coronavirus-covid-19-volunteering

19. Ghore, Y., \& Jiwa, F. (2020, 24). Voices from the Ground: Stories of Community Resilience \& Entrepreneurship in the Pandemic. From Poverty to Power. https://oxfamblogs.org/fp2p/voices-from-the-ground-stories-of-community-resilience-entrepreneurship-inthe-pandemic/

20. South, J., Stansfield, J., Amlôt, R., \& Weston, D. (2020). Sustaining and strengthening community resilience throughout the COVID-19 pandemic and beyond: Perspectives in Public Health. https://doi.org/10.1177/1757913920949582

21. IPSOS. (2020). Social cohesion in the pandemic age: A focus on Canada.

22. CARE International UK. (n.d.). Understanding resilience: Perspectives from Syrians.

23. IFRC. (2014). IFRC framework for community resilience. International Federation of the Red Cross and Red Crescent Societies (IFRC).

24. Wulff, K., Donato, D., \& Lurie, N. (2015). What Is Health Resilience and How Can We Build It? Annual Review of Public Health. https://doi.org/10.1146/annurev-publhealth-031914-122829

25. The TEN Essentials for Making Cities Resilient-Toolkit_Beta Version: Campaign. (n.d.). Retrieved 13 December 2020, from https://www.unisdr.org/campaign/resilientcities/toolkit/article/the-ten-essentials-for-making-cities-resilient

26. Hong Kong's Community Resilience Fund: An example of flexibility of social investment for COVID-19. (2020, August 21). Alliance Magazine. https:/www.alliancemagazine.org/blog/hong-kongs-community-resilience-fund-an-example-of-flexibility-ofsocial-investment-for-covid-19/

27. Global Resilience Fund Offers Flex Funding for Women and Girls . (2020, June 9). Philanthropy Women https://philanthropywomen.org/activism/global-resilience-fund-offers-flex-funding-for-women-and-girls/ 